\title{
Use of the concession agreements for the attraction of investments into the urban improvement
}

\author{
Oksana Feoktistova ${ }^{1}$, Elena Akimova ${ }^{1, *}$, Lubov Chaykovskaya ${ }^{3}$, and Alexey Chaykovskiy ${ }^{3}$ \\ ${ }^{1}$ Moscow State Technical University of Civil Aviation, 20, Kronshtadtsky blvd, 125993, Moscow, \\ Russia \\ ${ }^{2}$ Moscow State University of Civil Engineering, 26, Yaroslavskoye sh., 129337, Moscow, Russia \\ ${ }^{3}$ Plekhanov Russian University of Economics, Stremyanny per., 36, Moscow, Russia
}

\begin{abstract}
The objective of this research is to develop some recommendations on the creation of comfortable public vacation spots (parks, etc.), which would be attractive to inhabitants and at the same time could attract investments of small business through cooperation of the authorities and entrepreneurs. The paper supports the idea about the possibility of the use of the concession mechanism for this purpose. Though such projects are still rare in the Russian Federation at the moment, the authors study few successful projects, implemented, proving their viability. The schemes of implementation of the projects of the urban improvement due to concessions, works sharing, responsibility sharing as well as the allocation of project risks between the participants are considered in this paper. The principles, which make the projects effective, are formulated. The results, received within this research, can be useful both for the authorities during drawing up the regional and municipal programmes of urban improvement and development, and for the private investors, interested in such investments.
\end{abstract}

\section{Introduction}

Works on improvement and gardening in the Russwan cities are carried out mainly at the expense of local budgets. The expensive projects (including those developed by special architectural bureaus and companies) can be implemented only in large and rich cities. The programmes of urban improvement can also be co-financed from higher budgets, but the volumes of such financial supzort are usually small.

Thus, because of lack of local budgets' funds and the availability of more priority directions for their investment the sphere of the urban improvement remains "chronically" underfunded in the majority of the cities. Therefore, the authorities are interested in the attraction of the off-budget investments in such projects. In addition, business participation allows to apply new technologies, including more eco-friendly technologies of improvement and also to provide effective management at the facilities of the city infrastructure.

\footnotetext{
*Corresponding author: elena.chibisova_metr@mail.ru
} 
Certain support from business is obtained by territories of the large companies' presence, as they are engaged in development of public spaces within the programmes of social responsibility. Implementing projects on construction and reconstruction of parks, squares, embankments, sports grounds or playgrounds, large business creates favorable conditions for the specialists and makes these cities more attractive to life of people in general. At the same time business does not seek to make such initiatives paid back as this purpose is not initially set in the projects of this sort.

The projects of the improvement of city spaces implemented in the format of concessions are still not numerous in Russia. However, the available successful experience is worth studying. Thus, the subject of this paper is considered to be rather relevant.

The principles of the implementation of the projects of urban improvement, works sharing, responsibility sharing and the allocation of the project risks are formulated in the paper. The recommendations, offered within this research, can be useful for the improvement of urban areas of the country.

\section{Materials and Methods}

When carrying out the research, various scientific methods, such as synthesis and analysis of the studied matters and results, as well as the methods of economical-and-statistical, system-and-analytical and comparative analysis were used. The research relied on studying of domestic and foreign literature, analytical materials as well as statistical data of World bank, Sberbank, the websites of the studied projects, sites of federal and municipal authorities, materials by the National Public-and-private partnership Center, VEB Infrastructure Join Stock Company, and by InfraOne Research analytical agency.

Some successful examples of implementation of the projects of improvement of the city territories due to concessions were studied within the conducted research $[1,2,3]$ :

- "Polyana", the park of sports entertainments in Irkutsk;

- "Solar Road", the park embankment in Irkutsk, which will occupy the area of 26 hectares in the future, though only 3 hectares are involved now; about 100 million investments have been enclosed already;

- Reconstruction of "The Park in the 45th Residential district" in Surgut for the purpose of its use for the organization of rest of citizens and for tourism. Total amount of capital costs made up 200 million roubles. The initial cost of the property is 20.632 million roubles;

- At the beginning of 2019 the programme of business practical work "Open lands" was developed in the Baikal region. Five territories for which five participating teams have developed their development projects were involved in that practical work. AS the result each team created the concept of the project, the master plan, the financial plan, investment lots, legal structure of the park and the package of necessary documents for the start-up.

The park of sports entertainments "Polyana" located on the area of 4.5 hectares presents the format of active holiday and sport, absolutely new in Irkutsk. It is located in the specially created ecological environment which is at the same time in the city; and that makes this facility especially attractive and available for the citizens. It is the project with qualitative infrastructure and 15 facilities for improvement, sport and active holiday for the whole family. There are the highest rope park in Siberia, the biggest in the region paintball site, the veyk-station, soccer and volleyball courts, hiring office, bathing complex, pool, "Fort Boyard" quest show, cafe and grill lodges. It actively involves the adjacent territory. Numerous islands are used as running and bicycle routes in the summer and routes for fans of cross-country skis in the winter. The channels between islands turn into the route for kayakers in the summer. It is allowed to organize picnics and to play soccer on the glades. Investments into the park have made 70 million roubles. But taking into account that there 
are about 3500 people consuming various paid services a day here, such investments will pay off quickly enough.

The "Solar Road" project is unique in many respects. It is created on the basis of the concessionary agreement with the administration of Irkutsk and has already proved that such form of cooperation is efficient. It is the first example, still not having analogs in the region, which is made completely on the author's project with the specialization. "The Solar road" is the vacation spot for inhabitants of Irkutsk with all the necessary infrastructure, including cafes, restaurants, zoo, summer pool and also beautiful large-scale holidays and festivals. So far the first stage of the project, implemented at the site near the Angara ice breaker is completed; the continuation up to the pier "Rocket" and to the pool is being realized. The complex territory for rest of inhabitants and city visitors (the boulevard of 2.5 $\mathrm{km}$ long with facilities for entertainments, sports activities and additional education) has to appear according to the project in the residential district Solar y 2022.

Investments into the park have already made about 100 million roubles, including 34 million, which are the means of private investors, spent for the urban improvement and infrastructure. 6.3 million roubles have been also allocated according to the municipal programme "Comfortable Urban Environment". Nowadays 5000 people visit the park every day. In 2018 the "Solar Road" park embankment has been included in the collection of best practices in the sphere of tourism of Russia, imlemented on the basis of municipal and private partnership.

\section{Results}

Nowadays 32 projects are implemented in the sphere of improvement of the cities in Russia. Most of the projects on the urban improvement (nearly $70 \%$ of total quantity) are implemented in the form of concessionary agreements.

Not only improvement of the territory is planned, but also the complex of actions for the creation of venues of leisure and rest which are capable to bring income from commercial activity is provided within concessionary agreements as a rule. At the same time the concessionaire often bears all the commercial risks, so he or she is directly interested in creating the demanded facility and to provision the population with high-quality services. Direct collecting of payment from consumers for the use of the facility and as well as other commercial activity is the most widespread mechanism of return of investments. For example, the activity in the field of the development of physical culture and mass sport, excursions and exhibition activity, activity of parks with attractions, zoos, other actions, rest, including placement of modular facilities of public catering and non-stationary shopping facilities are meant.

The essential conditions of the studied concessionary agreement include:

- obligations of the concessionaire for the creation and (or) reconstruction of the subject of the agreement, as well as it;

- validity period of the concessionary agreement;

- technical-and-economic indicators of subject of the concessionary agreement [4];

- term of transfer of the concessionary agreement subject to the concessionaire;

- order of granting land plots to the concessionaire;

- methods of ensuring execution by the concessionaire of obligations under the concessionary agreement, the amount of the provided support and term for which it is provided;

- amount of concession payment, form (or forms), order and terms of its introduction;

- order of reimbursement of the expenses of the parties in case of early termination of the concessionary agreement; 
- obligations of the concessor and (or) the concessionaire for the preparation of the territory necessary for creation and (or) reconstruction of the subject of concessionary agreement and (or) for the implementation of the activity provided by concessionary agreement;

- the volume of the gross revenue received by the concessionaire within the implementation of the concessionary agreement [4]

- other essential conditions, provided by the legislation [5].

Organizational scheme of the standard model implementation, created on the basis of data on the projects, provided on the ROSINFRA platform, is presented in the Figure 1.

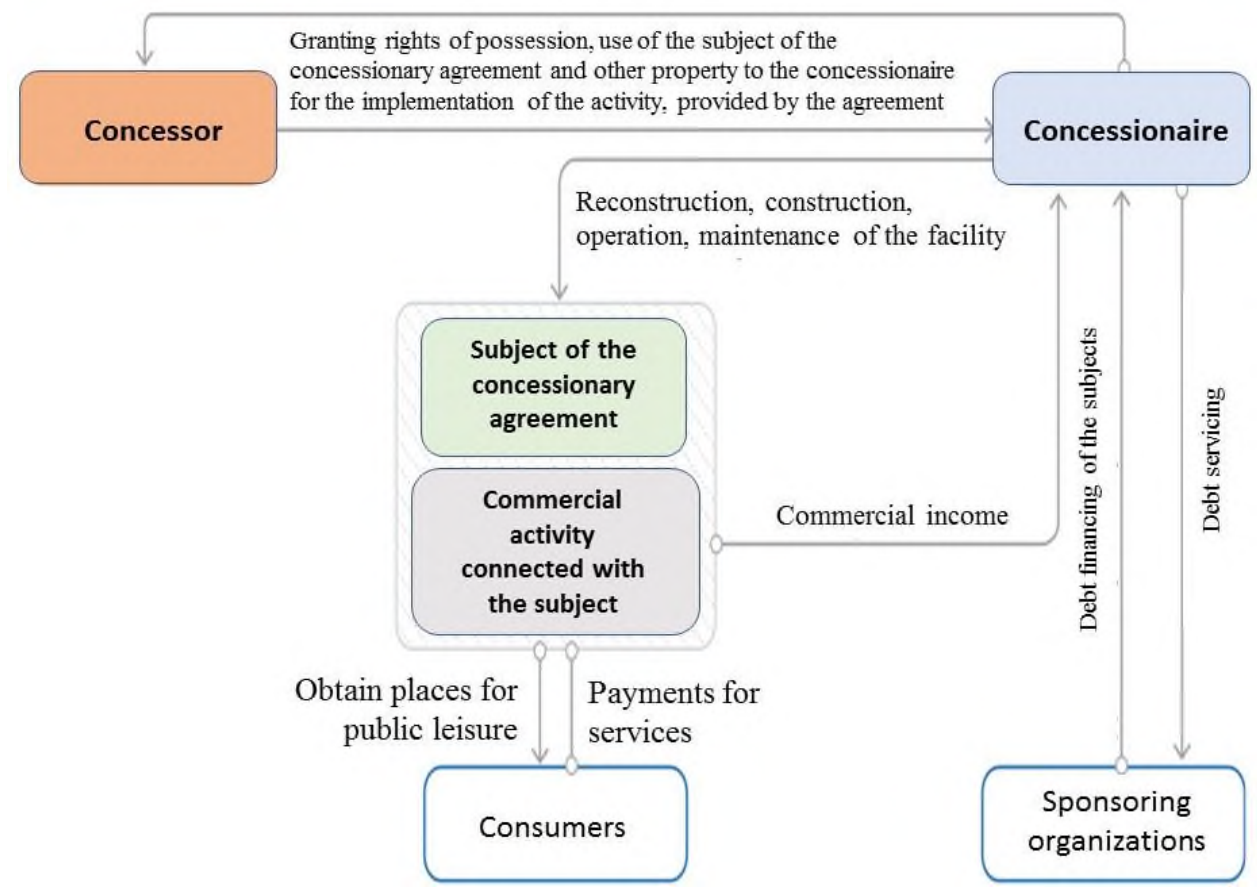

Fig. 1. Organizational scheme of the standard concessionary model.

The general feature is that the operator (business company) is created for each project. The operator gets the land plot (usually from 3 to 10 hectares) with the arrangement near the mass housing estate and/or in the place, attractive to tourists from the municipality as a long-term lease. The operator develops the concept of the territory development, its zoning for this site and breaks the area of future park (other facilities) into entrepreneurial lots (subjects of residents) for investments from small business. The lots include improvement and infrastructure. The park is designed as a modern public space, attractive for residents, with certain specialization (such as sport, rest, health improvement, etc.).

The subsequent tasks of the operator consist in the increase in flow of visitors (organization of marketing of the territory), keeping the concept and development of the park. The maintenance of the park is performed due to the business which is working and earning from its territory when rendering services to inhabitants.

Key stages of the work on the complex projects of parks (other facilities, including preparation, implementation and support, management and development $[6,7]$, are provided in Table 1. 
Table 1. Stages of work on the project of the urban improvement.

\begin{tabular}{|c|c|c|}
\hline Preparation & Implementation & $\begin{array}{c}\text { Management and } \\
\text { development }\end{array}$ \\
\hline $\begin{array}{l}\checkmark \text { Choice of the land plot } \\
\checkmark \text { Concept of the project } \\
\checkmark \text { Public hearings. } \\
\text { Involvement of } \\
\text { inhabitants and } \\
\text { investors in the } \\
\text { participating } \\
\text { collaborative } \\
\checkmark \text { Master-plan of the } \\
\text { facility } \\
\checkmark \text { Financial plan of the } \\
\text { facility } \\
\checkmark \text { Legal structure } \\
\text { (agreement with the } \\
\text { investor) } \\
\checkmark \text { Packed investment lots } \\
\text { for the sale by } \\
\text { entrepreneurs }\end{array}$ & $\begin{array}{c}\checkmark \text { Attracting investors } \\
\checkmark \text { Booking of lots by the } \\
\text { entrepreneurs } \\
\checkmark \text { Approval of the master-plan } \\
\checkmark \text { Design and estimate } \\
\text { documentation on infrastructure } \\
\text { creation, urban improvement } \\
\text { and construction. } \\
\checkmark \text { Statement and coordination of } \\
\text { the price for each lot. } \\
\checkmark \text { Refining of the cost part of the } \\
\text { project estimate and the cost of } \\
\text { each lot } \\
\checkmark \text { Environmental impact } \\
\text { assessment } \\
\checkmark \text { Connection of engineering } \\
\text { infrastructure (electricity, water } \\
\text { supply, sewage system) } \\
\checkmark \text { Conclusion of the investment } \\
\text { agreements } \\
\checkmark \text { Land surveying and agreements } \\
\text { of lease/sublease } \\
\checkmark \text { Connection of networks, } \\
\text { construction and urban } \\
\text { improvement (including } \\
\text { architectural supervision) }\end{array}$ & $\begin{array}{c}\checkmark \text { Administrative team } \\
\checkmark \text { Conclusion the contracts on } \\
\text { management and maintenance } \\
\text { of the territory } \\
\checkmark \text { Relationship with the residents. } \\
\text { Determination of rules for } \\
\text { apportionment of expenses } \\
\text { among the investors (residents) } \\
\checkmark \text { Activity implementation: } \\
\text { cleaning of the territory, } \\
\text { support, electricity and water } \\
\text { supply, advertising, PR, } \\
\text { payment for lease of sites and } \\
\text { for the maintenance of the } \\
\text { territory } \\
\checkmark \text { Holding actions } \\
\checkmark \text { Keeping the concept and } \\
\text { specialization of lots } \\
\checkmark \text { Collecting of feedback from the } \\
\text { users, inhabitants for the } \\
\text { improvement of quality and } \\
\text { support of relevance of services } \\
\checkmark \text { Expansion of the territory }\end{array}$ \\
\hline
\end{tabular}

During the project implementation the responsibility of the participants of the agreement (Table 2) is distributed as follows.

The managing company is engaged in the concept of the project, registration of lease of the site, drawing up the general plan and architecture, attracting investors, urban improvement, construction of networks, management of the territory, control of observance of economic regulations, quality control of the services provided by the residents. The managing company does not own facilities in parks, keeps objectivity and neutrality in activities for the development of the project.

The resident (small business) performs sublease of the land plots on the basis simplified, makes contribution to improvement of the park, takes part in management of the territory, builds the park facilities, operates them.

During the projects implementation the municipal authority acts as the partner, providing the land plot in long-term lease (auction or concession for 20-40 years), quickly agreeing on the current issues in operating mode, providing privileges for connections to the networks (at the moment the operating parks have not received such privileges yet, but there is process of preparation for such decision across similar territories). The municipality is also engaged in the improvement of the territory adjacent to the leased site, information support, interaction with inhabitants, etc. [8,9] 
Table 2. Responsibility zones during the urban improvement projects implementation.

\begin{tabular}{|c|c|c|}
\hline Managing company & Resident (small business) & Authorities (the partner) \\
\hline $\begin{array}{c}\checkmark \text { Concept of the project } \\
\checkmark \text { Registration of lease of } \\
\text { the site } \\
\checkmark \text { General plan and } \\
\text { architecture } \\
\checkmark \text { Attracting investors } \\
\text { (small business) } \\
\checkmark \text { Urban improvement, } \\
\text { networks construction } \\
\checkmark \text { Management of the } \\
\text { territory } \\
\checkmark \text { Control of respect for } \\
\text { environmental standards } \\
\checkmark \text { Quality control of the } \\
\text { services provided by } \\
\text { residents } \\
\checkmark \text { The managing company } \\
\text { does not own facilities in } \\
\text { parks, keeps objectivity } \\
\text { and neutrality in } \\
\text { activities for } \\
\text { development of the } \\
\text { project. }\end{array}$ & $\begin{array}{c}\checkmark \text { Sublease of the land plots on } \\
\text { the simplified basis } \\
\checkmark \text { Contribution to urban } \\
\text { improvement } \\
\checkmark \text { Construction of the facility } \\
\checkmark \text { Management and marketing of } \\
\text { the facilities }\end{array}$ & $\begin{array}{c}\checkmark \text { During implementation of each } \\
\text { project the regional and } \\
\text { municipal authorities act as } \\
\text { partners, as the created spaces } \\
\text { perform the important social } \\
\text { function. } \\
\checkmark \text { Granting the land plot in long- } \\
\text { term lease (auction or } \\
\text { concession for } 20-40 \text { years). } \\
\checkmark \text { Expeditious coordination in } \\
\text { operating mode. } \\
\checkmark \text { Privileges for connections to } \\
\text { networks. } \\
\checkmark \text { Improvement of the territory } \\
\text { adjacent to the site which is in } \\
\text { lease. } \\
\checkmark \text { Information support. } \\
\checkmark \text { Interaction with inhabitants. } \\
\checkmark \text { Collaborative design. }\end{array}$ \\
\hline
\end{tabular}

According to the allocated stages of the project and the zones of responsibility the distribution of risks among the participants is made (Fig. 2).

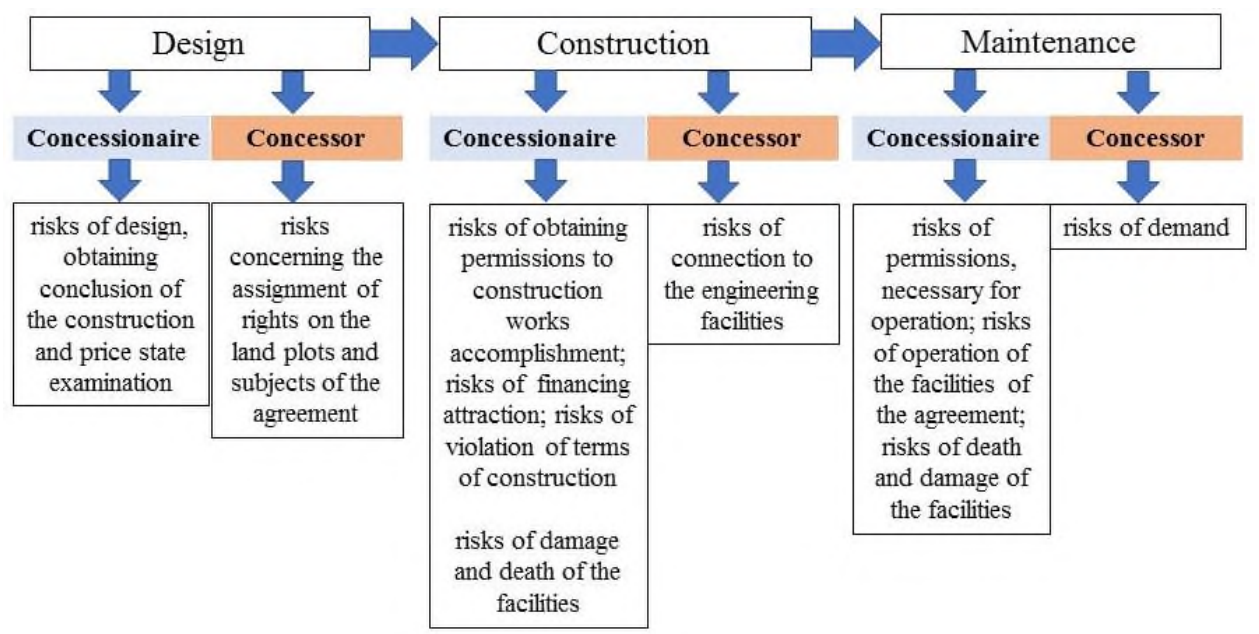

Fig. 2. Distribution of risks among the participants.

\section{Discussion}

Meanwhile there are serious barriers, preventing the development of concession mechanism for the urban improvement. Many municipalities got used to so-called "manual control" over the accountable facilities. That is quite explainable that municipalities fear of the fact that if they are deprived of managerial levers, they will not be able to interfere into the 
situation in case of any force majeure. Besides, the regional authorities do not realize, what kind of price policy will be conducted by the private investors, whether the investors will have incentives to modernize the infrastructure transferred to them.

One more bad trend is that not all the concessionaires who have won the competition, are really going to conclude the concessionary agreement. Some of them demonstrate their desire to enter into public-and-private partnership, receive certain benefit from the finance accumulation, but then refuse the agreement. [3, 10].

At last, sometimes the municipal authorities just fear of any innovations in principle.

Nevertheless, the answer to the doubts and criticism exists.

The municipal authority needs to reduce risks of creation of such projects. For this purpose, it is necessary to perform concession monitoring, to check reliability of the operator of the project who, in turn, has to pick up responsible resident partners, keep track of compliance to plans, accurately and unambiguously recorded in the agreement. Control of activity of parks, territories and other facilities by the departments of architecture of the municipality, informing managing company on all municipal, regional, federal programmes which can contribute to the accelerated effective development of the created public spaces are necessary.

According to the authors, it is important that the creation of parks was surely synchronized with the programmes of urban improvement, support of mass sports events and festive actions in the municipality.

In a broader sense the projects of urban improvement of separate facilities have to be built in the system of executed regional and municipal programmes as well as the existing programmes and those that are planned for the future $[11,12]$. That will correspond to the principle of system approach to the urban environment, proclaimed by Ministry of construction of the Russian Federation.

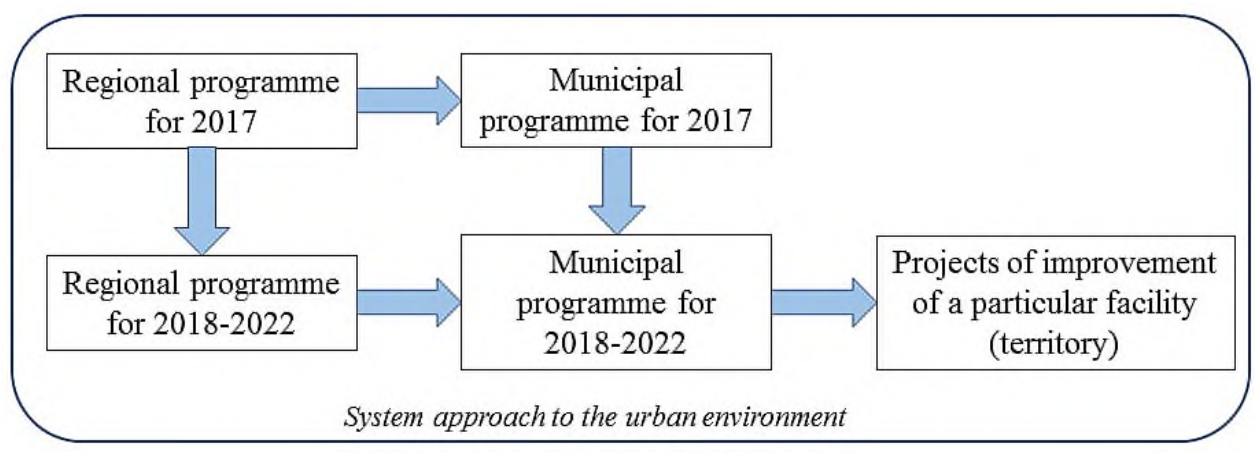

Fig. 3. System approach to the urban environment $[13,14,15]$.

Then it is necessary to observe the following principles for successful implementation of projects of urban improvement at the expense of concessionary agreements:

- Synergy. Each facility in the park supplements all its site, but does not duplicate the existing facilities, the front competition is not allowed; that gives partnership among the facilities;

- Partnership. Horizontal structure of communications among the authorities, operator, resident entrepreneurs.

- Sustainable development of the territory as the balance of interests of inhabitants, economy and ecology.

- Accent. Each facility in the park ought to be the main business of the entrepreneur, who has established it;

- Free of charge. Entrance on the territory of specialized parks ought to be free for the inhabitants. 


\section{Conclusions}

Successful improvement of urban areas can be performed and the achievement of high economic, social and environmental efficiency is possible, in case of constructive cooperation of private investors and the city administration within the concessionary agreements. The administration has to support the entrepreneurs when it is necessary to approve carrying out large-scale city holidays in the territories of parks, to advise partners on the matters of municipal services and changes of the legislation. Some principles have to be observed, including principles of

- synergy,

- partnership,

- sustainable development of the territories,

- focus of the entrepreneur established the facility, on its functioning,

- availability of the territory and free of charge entrance for the inhabitants,

- acquisition of income from the commercial services acting in the territory.

Harmonious work and coordination of actions by business and the authorities will allow to realize the planned development of the territory of the park, more effectively, to provide sufficient financing and to satisfy the interests of all the participants.

\section{References}

1. Z.K. Kondratenko, Eurasian legal magazine 11(126), 147-149 (2018)

2. A. Krylov, Experience of concession on improvement of public spaces. Creation of parks as municipal and private partner projects, http://cmokhv.ru/materials/news20191028-m/

3. Institute of City Economy Fund, Pluses and minuses of the concessionary agreement, https://expert.ru/northwest/2013/23/kontsessiya-domashnego-prigotovleniya/

4. A. Yumatov, Intelligence. Innovations. Investments S1, 51-54 (2012)

5. E. Vasilyeva, Y. Krupnov, E3S Web of Conferences 164, 10037 (2020)

6. I. Polyakova, E. Vasilyeva, E3S Web of Conferences 110, 02162 (2019)

7. C.A.T. Tovar, Bitacora Urbano Territorial 23(2), 1-12 (2013)

8. Junko Tamura, Shinya Miyazaki, Kentaro Honma, Journal of Architecture and Planning (Transactions of AIJ) 79(696), 475-482 (2014)

9. E. Vasilyeva, MATEC Web of Conferences 193, 01025 (2018)

10. E. Vasilyeva, A. Mottaeva, E3S Web of Conferences 91, 08051 (2019)

11. Kibrom Abay, Luca Tiberti, Tsega Gebrekristos Mezgebo, Meron Hailu, SSRN Electronic Journal 02 (2020) 10.2139/ssrn.3600990

12. E. Vasilyeva, IOP Conference Series: Earth and Environmental Science 90(1), 012216 (2017) DOI: 10.1088/1755-1315/90/1/012216

13. E. Vasilyeva, A. Nelyubov, E3S Web of Conferences 217, 07009 (2020)

14. A. Mottaeva, E3S Web of Conferences 110, 02164 (2019) doi.org/10.1051/e3sconf /201911002164

15. E. Anoshkina, E. Markovskaya, A. Mottaeva, As. Mottaeva, E3S Web of Conferences 210, 13022 (2020) https://doi.org/10.1051/e3sconf/202021013022

16. Order of the Ministry of Regional Development of the Russian Federation of October 1, 2013 N 359/GS (Moscow, 2013) 